\title{
Physical education and sports students' education quality satisfaction level
}

\author{
Numan Bahadir KAYISOGLU, Yilmaz YUKSEL
}

Karabuk University, Hasan Doğan School of Physical Education and Sports

This study was presented as a poster presentation in ERPA 2015 Congress, Athens, Greece.

Address Correspondence to B. Kayisoglu, e-mail: bahadirkayisoglu@gmail.com

\begin{abstract}
The purpose of this descriptive study carried out through survey method was to determine the satisfaction levels of the students of Hasan Doğan School of Physical Education and Sports at Karabük University with regard to educational services provided by the department. The study focused on the factors like age, gender, department and grade level. The study group of the research, consisting of 361 students, was chosen randomly from the students who attended the department of Physical Education and Sport Teaching and Sports Management in the academic year of 2014-2015. The data of the study were collected through an adapted 5-point likert questionnaire. Cronbach's alpha of the questionnaire was .94. Results indicated that student's satisfaction level in physical condition of the department is high but the level of efficiency of course and lecturers is moderate.
\end{abstract}

Keywords: Higher education, learning environment, student satisfaction, quality in higher education.

\section{INTRODUCTION}

The research in the field of education and educational institutions aims to increase the efficiency of the educational process. To achieve this aim, quality and productivity concepts are often discussed. Education sector is growing very rapidly all over the world. Globalization and digital revolution has created a demand for new and varied disciplines in education. Many countries are now shifting their economies from manufacturing to services sectors, developing and developed. Now the education sector has importance as other sectors of the economy. The cost of providing education has gone up manifold due to better teaching methodologies and learning instruments with rising inflation worldwide. Because of the increase in the number of institutions in higher education there is an intense competition in this sector. Number of new institutions has been founded and enrolment is also on the rise (15). Students can get information easily and instantly with the help of technology. In this competitive environment only those institutions can stand out which are providing quality education and constructive environment to their students, since these factors can influence their choice of admission. Such factors can satisfy students to their institutions and can affect their decisions to attend.
Although there is a significant amount of research on student satisfaction, Benjamin \& Hollings (4), Lee et al. (19) and Harvey (13) argue that student satisfaction is an important issue that has not yet been fully searched. Satisfaction or dissatisfaction with a university or faculty does not only affect student's personal performance $(3,26)$ and the competitive advantage of universities in an ever-increasing competitive environment (19).

Aldridge \& Rowley (2) state that according to students' opinion, good quality education correlates with better learning opportunities, and that levels of satisfaction or dissatisfaction are strong predictors of learning success/failure. Satisfied students are crucial to the success of any institution of higher learning. Deshields et al. (8) state that higher education institutions are focus on identifying and satisfying the needs and expectations of their students in areas such as academic achievement and learning facilities, and that the students' satisfaction positively influences their learning effectiveness.

There is an increase in the number of study which is studying of student satisfaction in colleges and universities in all over the word. There are too much factors which was identified that can potentially affect the students satisfaction to 
different education services provided by the universities. Students' informal contacts with faculty members were consistently related to withdrawal/persistence decisions (27). Retention of student was often thought as an indication of student satisfaction with their university program and, hence, indirectly, the quality of the university education. Indeed, a significant correlation can be observed between university ranking and retention rate universities close to the top of ranking lists tend to have high retention rates. (9). Yu \& Dean (29) examined that both positive and negative emotions and cognitive component of satisfaction correlate with loyalty and that affective component serves as a better predictor of customer loyalty than the cognitive factor. Palacio et al. (25) conducted a study on Spanish university students; university image, its reputation, found to influence student satisfaction at a Spanish university. The results of a study conducted by Mayo et al. (21) illustrated that conflicting family/work demands, financial issues and academic concerns were the factors identified by students as possible reasons for attrition. Navarro et al. (24) examined Spanish university students for their satisfaction with educational offers made by the universities. The results of the study expressed that the teaching staff, the teaching methods and course administration were key elements to achieving student satisfaction and their subsequent loyalty. Aldemir \& Gülcan (1) examined the Turkish students' satisfaction in higher education. The results of study showed that for some Turkish university students, the quality of instructors, education, textbooks and being female and informed before attending university considered to important factors of satisfaction. Mai (20) studied the student satisfaction in higher education and its influential factors. It was found that the overall impression of the school, overall impression of the quality of the education, teachers expertise and their interest in their subject, the quality and accessibility of IT facilities and the prospects of the degree furthering students careers were the most influential predictors of the students satisfaction. Similarly Deshields et al. (8) found that faculty performance and classes were the key elements which determined the quality of college experience of students which in turn led to satisfaction. All studies emphasis on certain factors of education offerings which determine the students' satisfaction with education. Therefore, the objective of this study is to analyze the education satisfaction level of the students of Hasan Doğan
School of Physical Education and Sports which was founded in 2010.

\section{MATERIAL \& METHOD}

Survey method was used for this study that aims to examine the relationship between students' satisfaction and education offerings like teachers' expertise, courses offered, learning environment and classroom facilities. Survey method is an approach which is used to describe the past and current situation as it is (18). The participants of the study consisted of 361 students from physical education and sports teaching and sports management departments who are studying at Karabük University Hasan Doğan School of Sports.

An adapted questionnaire was used to find out students' satisfaction level. This questionnaire developed according to local educational environment on the basis of instruments used by Içli \& Vural (16) in their study. The questionnaire was comprised of two sections. Section 1 consisted of demographic attributes like age, gender, grade and department etc. Section 2 comprised of questions related to students satisfaction on teachers expertise, courses offered, learning environment and classroom facilities measured on a on a 5-point Likert scale ranging from "strongly agree" (1) to "strongly disagree" (5). Reliability analysis demonstrated the Cronbach's Alpha coefficients for this questionnaire was .94, which considered being relatively high and internally consistent (12). Before the questionnaire was filled by the students the purpose of the questionnaire was explained to each of them. Proper instructions were written on the questionnaire and further instructions were given to the students in order to fill the questionnaire properly.

Quantitative data were analyzed by using descriptive statistics, namely frequencies and percentages, means $(\mathrm{M})$ and standard deviations (SD). To do analysis, Independent Sample T-Test and one-way analyses of variance (Anova) were performed. When statistical difference was found in Anova test, analysis of the difference was determined by post hoc analysis of Tukey. All analyses were performed using the SPSS statistical package. The level of significance was set at 0.05 .

\section{RESULTS}

The objective of this study is to investigate of student's satisfaction level under different variables 
such as age, sex, etc. For this purpose various tests are performed and results are summarized below.

When we examined the frequency and percentage values of the students gained from the students satisfaction questionnaire the most often seen satisfaction level item is "The lighting of classrooms is sufficient" while the less frequently seen satisfaction level item is "The foreign language education is enough".
According to students' opinions, the highest five level of satisfaction and the lowest five items are listed respectively in Table 1 and Table 2.

T-Test was applied to measure the difference of satisfaction between male and female students. The result of $\mathrm{T}$-Test shows a significant difference between the responses of two groups (Table 3). The mean value of male students is greater than female students.

Table 1. Frequency of the highest level of the student's satisfaction.

\begin{tabular}{|c|c|c|c|c|c|c|c|c|c|c|}
\hline & \multicolumn{2}{|c|}{$\begin{array}{l}\text { Strongly } \\
\text { agree }\end{array}$} & \multicolumn{2}{|c|}{ Agree } & \multicolumn{2}{|c|}{$\begin{array}{l}\text { Neither agree } \\
\text { nor disagree }\end{array}$} & \multicolumn{2}{|c|}{ Disagree } & \multicolumn{2}{|c|}{$\begin{array}{l}\text { Strongly } \\
\text { disagree }\end{array}$} \\
\hline & $\mathrm{f}$ & $\%$ & $\mathrm{f}$ & $\%$ & $\mathrm{f}$ & $\%$ & $\mathrm{f}$ & $\%$ & $\mathrm{f}$ & $\%$ \\
\hline 30. The lighting of classrooms is sufficient & 158 & 43.8 & 127 & 35.2 & 49 & 13.6 & 11 & 3.0 & 16 & 4.4 \\
\hline 29. The heating of classrooms is sufficient & 148 & 41.0 & 122 & 33.8 & 57 & 15.8 & 15 & 4.2 & 19 & 5.3 \\
\hline 31. Classrooms are clean & 130 & 36.0 & 112 & 31.0 & 61 & 16.9 & 34 & 9.4 & 24 & 6.6 \\
\hline 33. Toilets and sinks are clean & 125 & 34.6 & 111 & 30.7 & 72 & 19.9 & 23 & 6.4 & 30 & 8.3 \\
\hline $\begin{array}{l}\text { 4. Teaching staff have sufficient } \\
\text { knowledge of their subject areas }\end{array}$ & 116 & 32.1 & 145 & 40.2 & 68 & 18.8 & 21 & 5.8 & 11 & 3.0 \\
\hline
\end{tabular}

Table 2. Frequency of the lowest level of the student's satisfaction.

\begin{tabular}{|c|c|c|c|c|c|c|c|c|c|c|}
\hline & \multicolumn{2}{|c|}{$\begin{array}{c}\text { Strongly } \\
\text { agree }\end{array}$} & \multicolumn{2}{|c|}{ Agree } & \multicolumn{2}{|c|}{$\begin{array}{l}\text { Neither agree } \\
\text { nor disagree }\end{array}$} & \multicolumn{2}{|c|}{ Disagree } & \multicolumn{2}{|c|}{ Strongly disagree } \\
\hline & $\mathrm{f}$ & $\%$ & $\mathrm{f}$ & $\%$ & $\mathrm{f}$ & $\%$ & $\mathrm{f}$ & $\%$ & $\mathrm{f}$ & $\%$ \\
\hline 19. The foreign language education is sufficient & 28 & 7.8 & 48 & 1.3 & 69 & 19.1 & 67 & 18.6 & 149 & 41.3 \\
\hline $\begin{array}{l}\text { 18. We have enough laboratories, workshops, } \\
\text { tools and equipment to support lectures }\end{array}$ & 37 & 10.2 & 68 & 18.8 & 106 & 29.4 & 70 & 19.4 & 80 & 22.2 \\
\hline 12. Faculty organize Technical visits, career day & 38 & 10.5 & 65 & 18.0 & 89 & 24.7 & 70 & 19.4 & 99 & 27.4 \\
\hline 24. Exam questions evaluated after each test & 41 & 11.4 & 73 & 20.2 & 135 & 37.4 & 61 & 16.9 & 51 & 14.1 \\
\hline $\begin{array}{l}\text { 14. Courses and content are sufficient to prepare } \\
\text { us for the working life }\end{array}$ & 43 & 11.9 & 91 & 25.2 & 114 & 31.6 & 55 & 15.2 & 58 & 16.1 \\
\hline
\end{tabular}

Table 3. Level of satisfaction between male and female students.

\begin{tabular}{lccccc}
\hline Gender & $\mathrm{n}$ & Mean & SD & $\mathrm{t}$ & $\mathrm{p}$ \\
\hline Male & 260 & 3.42 & 0.67 & & \\
Female & 101 & 3.20 & 0.66 & 2.718 & 0.007 \\
\hline
\end{tabular}

Table 4. Analysis of variance for age group.

\begin{tabular}{lrllccccccc}
\hline Group & \multicolumn{1}{c}{$\mathrm{n}$} & Mean & SD & \multicolumn{1}{c}{ SS } & $\mathrm{df}$ & MS & $\mathrm{F}$ & $\mathrm{p}$ & $\eta 2$ & Significant Difference \\
\hline & & & & & & & & & & \\
$17-19$ & 51 & 3.61 & 0.54 & 5.762 & 3 & 1.921 & & & & $17-19 \& 23-24$ \\
$20-22$ & 184 & 3.37 & 0.67 & 161.247 & 357 & 0.452 & & & \\
$23-24$ & 94 & 3.27 & 0.65 & 167.009 & 360 & & & 0.006 & 0.034 & $17-19 \& 25+$ \\
$25+$ & 32 & 3.13 & 0.85 & & & & & & & \\
\hline
\end{tabular}


Table 5. Analysis of variance for grade level.

\begin{tabular}{crrrrrrrrrr}
\hline Grade & $\mathrm{n}$ & Mean & SD & SS & df & MS & F & p & $\eta 2$ & Significant Difference \\
\hline $1^{\text {st }}$ grade & 198 & 3.54 & 0.66 & 20.730 & 3 & 6.910 & & & & 1-3. Grade \\
$2^{\text {nd }}$ grade & 58 & 3.38 & 0.49 & 146.279 & 357 & 0.410 & & & & 1-4. Grade \\
$3^{\text {rd }}$ grade & 39 & 2.94 & 0.58 & 167.009 & 360 & & & & & 2-3. Grade \\
$4^{\text {th }}$ grade & 66 & 3.02 & 0.70 & & & & & & & 2-4. Grade \\
\hline
\end{tabular}

Table 6. Group differences for department.

\begin{tabular}{lccccc}
\hline Department & $\mathrm{n}$ & Mean & SD & $\mathrm{t}$ & $\mathrm{p}$ \\
\hline Physical Education and Sports Teaching & 210 & 3.40 & 0.68 & & \\
Sports Management & 151 & 3.29 & 0.67 & 1.540 & 0.124 \\
\hline
\end{tabular}

Table 7. Analysis of variance for monthly income.

\begin{tabular}{lrccccccc}
\hline \multicolumn{1}{c}{ Monthly Income } & \multicolumn{1}{c}{$\mathrm{n}$} & Mean & SD & SS & df & MS & F & $\mathrm{p}$ \\
\hline $0-1000 \mathrm{TL}$ & 254 & 3.35 & 0.68 & 0.592 & 3 & .197 & & \\
$1001-2500 \mathrm{TL}$ & 76 & 3.35 & 0.57 & 166.417 & 357 & .466 & .423 & .737 \\
2501-4000 TL & 20 & 3.49 & 0.60 & 167.009 & 360 & & & \\
$4001 \mathrm{TL}$ and high & 11 & 3.21 & 1.25 & & & & & \\
\hline
\end{tabular}

Table 4 presents the ANOVA results that suggested student's satisfaction level were significantly different for age groups. Tukey's post hoc test was applied to compare the significant differences between age groups. There was a statistically significant between 17-19 \& 23-24 and $17-19 \& 25+$ age group. When the size of the effect was examined, it observed to be medium.

Table 5 presents the ANOVA results that suggested student's satisfaction level were

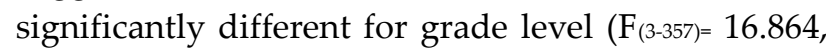
$\mathrm{p}<.05, \eta 2=0.034)$. According to Tukey comparison test, the difference was specially found between 1-3. grade, 1-4. grade, 2-3. grade and 2-4. grade. When the size of the effect was examined, it observed to be high.

Table 6 shows the independent t-test results. According to the independent $t$-test results, there was no significant difference between the means of physical education and sports teaching student's (M $=3.40, \mathrm{SD}=.68)$ and sports management student's $(\mathrm{M}=3.29, \mathrm{SD}=.67)$ satisfaction level.

Table 7 presents the ANOVA results of the monthly income. According to Table 7, there is no significant difference between monthly income and student's satisfaction $(\mathrm{F}(3-357)=.423, \mathrm{p}>.05)$.

\section{DISCUSSION}

The results indicate that there are significant differences between the satisfaction level of male and female students. Although students in both gender are satisfied with the education, male students expressed higher levels of satisfaction compared female. It indicates that female students are lesser satisfied with their education as compared to male students. Women get fewer opportunities than men in education. The proportion of female students is also smaller than male students both in private and public sector universities. Female students face more problems in reaching and studying at university than male students. The reason female students are less satisfied than male students can be explained by making use of the expectation-performance theory of satisfaction. University education is a long-term process. Students who join a university or faculty with predetermined expectations start comparing their expectations with the performances of their respective educational institutions, during this rather long period. If expectations are not met, i.e. if the performance level is below the level of expectations, dissatisfaction occurs.

Fresh students (17-19 age group) seemed to be more satisfied than elder students (25+ age group). It seems that with age, some of the students do experience slight dissatisfaction, due to the increase in pressure, the stress of graduation and anxieties 
about what is expected from them after school. This is especially true for male students. The satisfaction of male and female students starts differing in and after junior class. Male students, due to enormous social conditioning (17) feel trapped between finding a job and the restrictions of the economic problem. Yetim (28) conducted a research among Turkish male university students, found that male students have a deeper feeling of mastery than female students and that this feeling of mastery is deeply rooted in their social conditioning.

The results concerning factors of satisfaction clearly show that academic factors, especially satisfaction with the faculty, explain student satisfaction more than the others. Guolla (11), Cashin \& Downey (6), Marsh (22), Conant (7) also pointed to the importance of the instructor's performance. Highly performing instructors' students are more satisfied not only with their instructors but also with their institutions. Thus, even if a Faculty administration performs poorly, their students remain satisfied as long as they have highly performing instructors. The quality delivered by the teaching staff is still viewed as an essential element in quality perception and satisfaction.

Other academic factors such as communication with the instructor in and outside the classroom $(10,14)$, the quality of education that professors provide and the textbooks that they choose, all relate to students' satisfaction. According to Aldemir \& Gülcan (1) most of the highly performing instructors also have satisfactory communication in and outside the class with their students. Because they are open to two-way communication and hence feedback, they usually come up with the best choices concerning textbooks. Thus, from the student's satisfaction point of view, it becomes crucial for university administrations to recruit, motivate and retain highly performing instructors. Thus, at least for the students of Hasan Doğan School of Physical Education and Sports, the quality of education, instructors, learning environment can be considered important factors of satisfaction.

\section{REFERENCES}

1. Aldemir C, Gülcan Y. Students Satisfaction in Higher Education: A Turkish Case. Higher Education Management and Policy, 2004; 16(2): 109-122.

2. Aldridge $S$, Rowely J. Measuring customer satisfaction in higher education. Quality Assurance in Education, 1998; 6(4): 197-204.
3. Bean JP, Bradley RK. Untangling the Satisfaction-Performance relation for College Students. Journal of Higher Education, 1986; 57(4):393-412

4. Benjamin M, Hollings A. Towards a Theory of Student Satisfaction: an Explanatory Study of the Quality of Student Life. Journal of College Student Development, 1995; 36(6): 574-586.

5. Campbell T A, Campbell DE. Faculty/student mentor program: effects on performance and retention, Research in Higher Education, 1997; 38(6): 727-742.

6. Cashin WE, Downey RG. Using global student rating items for summative evaluation. Journal of Educational Psychology, 1992; 84: 563-572.

7. Conant SJ, Brown JJ, Makura MP. Students are Important Consumers: Assessing Satisfaction in a Higher Education Context. Journal of Marketing Education, 1985; Summer: 1320.

8. DeShields Jr., OW, Kara A, Kaynak E. Determinants of business student satisfaction and retention in higher education: applying Herzberg's two factor theory. International Journal of Educational Management. 2005; 19(2): 28-139.

9. Druzdzel MJ, Glymour C. Application of the TETRAD II program to the study of student retention in US colleges. In Working notes of the AAAI-94 Workshop on Knowledge Discovery in Databases (KDD-94), 419-430, Seatle, WA, July 1994.

10. Fredericksen E, Pickett A, Shea P, Pelz W, Swan K. Student Satisfaction and Perceived Learning with Online Courses: Principles and Examples from the SUNY Learning Network. Journal of Asynchronous Learning Networks, 2000; 4 (2): 7 41.

11. Guolla M. Assessing the teaching quality to student satisfaction relationship: applied customer satisfaction research in the classroom. Journal of Marketing Theory \& Practice, 1999; 7(3): 87-96.

12. Hair JF, Anderson RE, Tatham RL, Black, WC. Multivariate Data Analysis, 5th ed., Prentice-Hall, Englewood Cliffs, NJ, 1998

13. Harvey L. Student Feedback: a Report to the Higher Education Funding Council for England, Centre for Research into Quality, University of Central England in Birmingham, Perry Barr, Birmingham, UK, 2001.

14. Hong KS. Relationship between Students' and Institutional Variables with Satisfaction and Learning from a Web-based Course. The Internet and Higher Education, 2002; 5(3): 267281.

15. Isani UAG, Virk ML. Higher education in Pakistan: a historical and futuristic perspective, Islamabad: National Book Foundation, 2005.

16. İçli G, Vural BB. Toplam Kalite Yönetimi ve Uygulamalari Çerçevesinde Kırklareli Üniversitesi Meslek Yüksekokullari Öğrenci Memnuniyeti Araştırması. Marmara Üniversitesi İ.I.B.F. Dergisi, 2010; 28(1):335-349.

17. Kağıtçıbaşı Ç. Çocuğun Değeri: Türkiye'de Değerler ve Doğurganlık, Bogaziçi Üniversitesi, İstanbul, 1981.

18. Karasar N. Bilimsel Araştırma Yöntemi. Ankara: Nobel Yayın Dağıtım, 2003. 
19. Lee G, Jolly N, Kench B, Gelonesi B. Factors Related to Student satisfaction with University 4th Pacific Rim, First Year in Higher Education Conference, 2000; 1-8.

20. Mai L. A Comparative Study between UK and US: The Student Satisfaction in Higher Education and its Influential Factors. Journal of Marketing Management, 2005; 21: 859-878.

21. Mayo DT, Helms MM, Codjoe HM. Reasons to remain in college: a comparison of high school and college students. The International Journal of Educational Management, 2004; 18(6): 360-367.

22. Marsh WH. A Multinational Perspective on students evaluation of teaching effectiveness: reply to Abrami and d'Apollina. Journal of Educational Psychology, 1991; 83: 416421.

23. Napoli AR, Wortman, PM. Psychological factors related to retention and early departure of two-year community college students. Research in Higher Education, 1998; 39(4): 419-455.

24. Navarro MM, Iglesias PM, Torres RP. A New Management Element for Universities: Satisfaction with the offered courses. International Journal of Educational Management, 2005; 19(6): 505-526.
25. Palacio AB, Menesses GD, Perez Perez, PJ. The configuration of the university image and its relationship with the satisfaction of students. Journal of Educational Administration, 2002; 40(5): 486-505.

26. Pike GR. The Effects of Background, Coursework, and Involvement on Student Grades and Satisfaction. Research in Higher Education, 1991; 32(1): 15-30.

27. Terenzini PT, Pascarella ET. Toward the validation of Tinto's model of college student attrition: A review of recent studies. Research in Higher Education (Historical Archive). 1980; 12(3):271-282.

28. Yetim U. The Impact of Individualism, Self-esteem and Feeling of Mastery on Life Satisfaction among the Turkish University Students and Academicians. Social Indicator Research, 2003; 61(3): 297-317.

29. Yu Y, Dean A. The contribution of emotional satisfaction to consumer loyalty. International Journal of Service Industry Management, 2001; 12(3): 234-250. 